\title{
Promosi Jabatan, Mutasi, Dan Motivasi Berprestasi Sebagai Upaya Meningkatkan Prestasi Kerja Aparatur Sipil Negara
}

\author{
Subandi \\ Badan Kepegawaian Daerah Kota Blitar
}

\begin{abstract}
As a public servant, a civil servant must demonstrate high work performance. High work performance is a form of evidence that the civil servants concerned can carry out the tasks carried out properly. Therefore, various personnel management policies have been pursued by the government in improving work performance, including mutation, promotion and motivation.

The purpose of this study was to find out the influence of achievement motivation, mutation and promotion of work performance of civil servants. Specifically, this study aims to determine the effect of (1) acbievement motivation on work. performance; (2) mutation of work performance; (3) promotion of work. performance; and (4) the significance of the influence of acbievement motivation, mutation, and promotion of work performance of civil servants in the Regional Civil Service Agency of the City of Blitar.

This study uses descriptive analysis method with a quantitative approach. The research sample used the entire population, namely all civil servants in the Regional Civil Service Agency of Blitar City were 35 people. Data obtained through instruments in the form of questionnaires with linkert scale. Data analysis using multiple linear regression.

The results showed that (1) achievement motivation had a positive and significant effect on work performance. (2) mutations have a positive and significant effect on work performance. (3) job promotion does not have a positive and significant effect on work performance. (4) collectively achievement motivation, mutation and promotion have a significant effect on job performance.

Keywords : work perfomance, civil servant, motivation abievement, mutation, position promotion.
\end{abstract}

\section{Latar Belakang}

Prestasi kerja disebut juga sebagai kinerja atau dalam bahasa inggris disebut dengan performance dengan kata lain prestasi kerja adalah hasil kerja secara kualitas dan kuantitas yang dicapai oleh seorang karyawan dalam melaksanakan tugasnya sesuai dengan tanggungjawab yang diberikan kepadanya (Mangkunegara, 2013). Salah satu tugas yang diberikan kepada pegawai negeri sipil adalah memberikan pelayanan publik yang profesional dan berkualitas. Hal ini tertuang dalam pasal 11 huruf c Undang-Undang Republik Indonesia No. 5 Tahun 2014 tentang Aparatur Sipil Negara.

Mangkunegara (2009) menyampaikan bahwa indikator prestasi kerja seorang pegawai adalah kualitas, kuantitas, pelaksanaan tugas dan tanggung jawab. Kualitas kerja bisa dilihat dari ketepatan, ketelitian, keterampilan, dan kebersihan hasil kerja. Kuantitas kerja diindikasikan dengan banyaknya hasil kerja sesuai dengan waktu yang ada dengan memperhatikan kecepatan kerja. Sedangkan pelaksanaan tugas dan tanggung jawab dapat dilihat dari pelaksanaan tugas dan akibat lebih jauh dari peranan tugas yang dilakukan.

Penilaian terhadap aspek aspek tersebut dilakukan setiap akhir tahun berdasarkan Peraturan Pemerintah Republik Indonesia Nomor 46 Tahun 2010 tentang Penilaian Prestasi Kerja Pgawai Negeri Sipil yang secara teknis diatur dengan Peraturan Kepala BKN No. 21 Tahun 2011.

Badan Kepegawaian Daerah Kota Blitar merupakan salah satu Organisasi perangkat daerah yang membantu Walikota sebagai pejabat yang berwenang dan pejabat yang menetapkan dalam penyelenggaraan pelaksana manajemen pegawai negeri sipil daerah sesuai dengan Undang-undang Nomor 5 Tahun 2014 tentang Aparatur Sipil Negara, memungkinkan untuk menyelenggarakan pelayanan manajemen aparatur sipil negara daerah di bidang penyusunan dan penetapan kebutuhan, pengadaan, pangkat dan jabatan pengembangan karier, pola karier, promosi, mutasi, penilaian kinerja, penghargaan, penegakan disiplin, kode etik dan perilaku, 
pemberhentian, pensiun dan perlindungan aparatur (Kota Blitar, 2017).

Dalam menjalankan tugas tersebut, Badan Kepegawaian Daerah Kota Blitar dijalankan oleh 1 (satu) orang kepala badan setingkat eselon II, 3 (tigas) orang kepala bidang dan sekretaris setingkat eselon III, 8 (delapan) kasubag dan kasubid setingkat eselon IV, dan 21 (dua puluh satu) jabatan fungsional umum. Struktur dan tata kerja organisasi perangkat daerah ini di atur dalam Peraturan Walikota Nomor 76 Tahun 2016 tentang Kedudukan, Susunan Organisasi, Tugas dan Fungsi Serta Tata Kerja Badan Kepegawaian Daerah.

Berdasarkan data yang dihimpun terkait dengan prestasi kerja yang ditunjukkan pegawai negeri sipil Badan Kepegawaian Daerah Kota Blitar, didapatkan data bahwa hampir $80 \quad \%$ menunjukkan pencapaian sasaran kerja baik dan $11.43 \%$ berprestasi kerja yang sanagt baik serta $88.57 \%$ berprestasi kerja baik.

Terkait dengan prestasi yang luar biasa tersebut, Handoko (2001) mengatakan bahwa keadaan pribadi seseorang dapat mendorongnya melakukan aktivitas tertentu untuk mencapai suatu tujuan. Salah satu motivasi kerja adalah need for achievement motivation. Mc. Clelland dalam Robbins (2013) menjelaskan bahwa motivasi berprestasi adalah dorongan dalam diri seseorang untuk melakukan atau mengerjakan suatu kegiatan atau tugas dengan sebaik-baiknya agar mencapai prestasi dengan predikat terpuji.

Semakin tinggi motivasi tersebut maka seseorang akan berusaha untuk menunjukkan prestasi kerja yang tinggi pula. Hal ini dibuktikan secara empiris oleh Saputro (2013) yang menyatakan bahwa motivasi berprestasi berpengaruh signifikan terhadap prestasi kerja seseorang. Lebih lanjut Rismawati (2016) membuktikan bahwa motivasi berprestasi berpengaruh signifikan terhadap prestasi kerja.

Selain diberi motivasi, seorang pegawai dapat dipindahkan dari atau ke bidang tugas yang berbeda baik posisi yang sama (transfer) atau yang lebih tinggi (promotion). Priansa (2016) menjelaskan bahwa transfer adalah bila pegawai tersebut dipindahkan dari satu bidang tugas ke bidang tugas lainnya amaupun tingka setrukturalnya. Sedangkan promosi menurut Rivai dan Sagal (2009) adalah apabila seorang pegawai dipindahkan dari satu pekerjaan ke pekerjaan lain yang lebih tinggi.

Pegawai yang baik yang dimutasi (transfer) atau promosi dapat menunjukkan prestasi kerja yang berbeda. Prestasi kerja yang berbeda-beda tersebut diakibatkan oleh kecocokan dan ketidakcocokan dengan bidang tugas yang baru (Mankuprawiran, 2011). Kecocokan dan ketidakcocokan yang timbul dapat dipengaruhi oleh faktor prestasi akdemis, faktor pengalaman, faktor kesehatan fisik, dan mental, faktor status perkawinan dan faktor usia (Priansa, 2016).

Secara empiris, pengaruh mutasi dan promosi jabatan terhadap prestasi kerja telah dibuktikan oleh Indrawan (2015) yang menyatakan bahwa mutasi dan promosi jabatan berpengaruh signifikan terhadap prestasi kerja akan tetapi pengaruh promosi jabatan terhadap prestasi kerja lebih dominan dari pada pengaruh mutasi terhadap prestasi kerja. Sementara itu Judas (2013) dalam penelitian menyatakan bahwa mutasi tidak signifikan berpengaruh terhadap prestasi kerja sedangkan promosi jabatan berpengaruh signifikan terhadap prestasi kerja.

Berkenaan dengan berbagai penjelasan di atas, peneliti mengambil judul "Pengaruh Motivasi Berprestasi, Mutasi Dan Promosi Jabatan Terhadap Prestasi Kerja Pegawai Negeri Sipil Badan Kepegawaian Daerah Kota Blitar.

\section{Prestasi Kerja}

Prestasi kerja adalah suatu hasil kerja yang dicapai seseorang dalam melakukan tugas-tugas yang dibebankan kepadanya yang didasarkan pada kecakapan, pengalaman, dan kesungguhan serta ketepatan waktu. Hasibuan (2010). Prestasi kerja adalah hasil kerja secara kualitas dan kuantitas yang dicapai oleh seorang pegawai dalam melaksanakan tugasnya sesuai dengan tanggung jawab yang diberikan kepadanya Mangkunegara (2013).

Sondang (2004: 225) prestasi kerja adalah suatu pendekatan dalam melakukan penilaian kerja para pegawai dimana terdapat berbagai faktor yaitu: 1 . Yang dinilai adalah manusia yang disamping memiliki kemampuan tertentu juga tidak luput dari berbagai kelemahan dan kekurangan. 2. Penilaian yang dilakukan pada serangkaian 
tolok ukur tertentu yang realistik, berkaitan langsung dengan tugas seorang serta kriteria yang ditetapkan dan diterapkan secara obyektif.

Menurut (Dharma, 2001) prestasi kerja adalah perbandingan antara penampilan seseorang dengan hasil yang diharapkan. Penilaian evaluasi kerja menunjukkan hasil yang telah dicapai pegawai selama ini. Menurut (Dessler, 2002) prestasi kerja karyawan adalah suatu informasi yang digunakan sebagai dasar pengambilan keputusan tentang promosi dan gaji.

Penilaian prestasi kerja ialah sebuah penilaian sistematis terhadap karyawan oleh atasannya atau beberapa ahli lainnya yang paham akan pelaksanaan pekerjaan oleh karyawan atau jabatan itu. Simamora (2002: 415) penilaian prestasi kerja ialah suatu alat yang bermanfaat tidak hanya untuk mengevaluasi kerja dari para karyawan, tetapi juga untuk mengembangkan dan memotivasi organisasi kalangan karyawan. Pendapat yang tidak jauh berbeda mengatakan bahwa penilaian prestasi kerja adalah proses melalui mana organisasi-organisasi mengevaluasi atau menilai prestasi kerja karyawan, kegiatan ini dapat memperbaiki keputusan-keputusan personalia dan memberikan umpan balik kepada karyawan tentang pelaksanaan kerja mereka (Handoko, 2001: 135).

\section{Motivasi}

Motivasi berasal dari kata motive (motif), yaitu apa yang menggerakkan atau mendorong seseorang melakukan sesuatu kegiatan. Motivasi secara sederhana dapat dirumuskan sebagai tindakan mendorong seseorang melakukan suatu kegiatan (pekerjaan), jadi seperti menekan tombol yang tepat untuk memperoleh reaksi yang diperlukan. Schiffman dan Kanuk (2000) mendefinisikan motivasi "Motivation can be described as driving force within individuals that impels them to action. This driving force is produced by state of tension, which exists as the result of an infulfilled need". Solomon (1999) mendefinisikan "motivation refers to the processes that cause people to behave as they do. If occurs when a need is aroused that the consumer wishes to satisfy. Once a need has been activated, a state of tension exists that drives the consumer to attempt to reduce or eliminate the need. Mowen dan Minor (1998) mendefinisikan "Motivation refers to an activated state within a person that leads to goal-directed behavior. It consists of the drives, urges, whises, or desires that initiate the sequence of events leading to a behavior"

Inilah yang disebut motivasi. Mc. Clelland, Atkinson dan kawan-kawan (Filley et. al, 1976) telah melakukan penelitian yang ekstensif dalam mengembangkan teori prestasi. Pada dasarnya motivasi seseorang ditentukan oleh tiga kebutuhan:

1. Kebutuhan akan kekuasaan (need for power)

2. Kebutuhan akan afiliasi (need for affiliation)

3. Kebutuhan akan keberhasilan (need for achievement)

Motivasi berprestasi menurut Mc. Clelland adalah timbulnya kegagalan para pemimpin menciptakan sistem insentif yang efektif, adalah karena adanya kekeliruan tentang manusia dan pekerjaannya.

\section{Mutasi}

Salah satu perwujudan kegiatan mutasi adalah pemindahan tenaga kerja dari satu tempat kerja ke tempat kerja lain (Moliodica, 2009).

\section{Pengertian Mutasi}

Siagian (2010) menjelaskan bawah mutasi atau pemindahan oleh sebagian masyarakat sudah dikenal, baik dalam lingkungan maupun di luar lingkungan perusahaan (pemerintahan). Perpindahan pegawai terjadi dalam setiap organisasi baik lembaga pemerintahan maupun organisasi perusahaan. Ada berbagai istilah perpindahan yang digunakan setiap organisasi, istilah yang umum digunakan adalah mutasi. Hasibuan (2002) menjelaskan bahwa istilah-istilah yang sama pengertiannya dengan mutasi adalah pemindahan, alih tugas, transfer dan job rotation karyawan.

Mutasi memiliki banyak arti yang dijelaskan oleh para ahli. Moekijat (1987) yang menggunakan istilah mutasi dengan istilah pemindahan menjelaskan bahwa pemindahan adalah suatu perubahan horizontal, bukan suatu kenaikan atau suatu penurunan. Sedangkan Simamora (2006) mengutarakan mutasi dengan istilah transfer yang berarti perpindahan 
seorang karyawan dari satu pekerjaan ke posisi lainnya yang gaji, tanggung jawab dan/atau jenjang organisasionalnya sama.

Hasibuan (2008) menyatakan bahwa mutasi adalah suatu perubahan posisi/jabatan/tempat/pekerjaan yang dilakukan baik secara horizontal maupun vertikal di dalam satu organisai. Selanjutnya menurut Sastrohadiwiryo (2002) mutasi adalah kegiatan ketenagakerjaan yang berhubungan dengan proses pemindahan fungsi, tanggung jawab, dan status ketenagakerjaan tenaga kerja ke situasi tertentu dengan tujuan agar tenaga kerja yang bersangkutan memperoleh kepuasan kerja yang mendalam dan dapat memberikan prestasi kerja yang semaksimal mungkin kepada perusahaan.

Nasution (1994) menjelaskan mutasi adalah kegiatan memindahkan pegawai dari unit/ bagian yang kelebihan tenaga ke unit/ bagian yang kekurangan tenaga atau yang memerlukan. Jadi, dapat disimpulkan bahwa mutasi diartikan sebagai perubahan mengenai atau pemindahan kerja/ jabatan lain dengan harapan pada jabatan baru itu dia akan lebih berkembang.

Sedangkan landasan hukum pelaksanaan mutasi, pengangkatan dan pemberhentian pegawai negeri sipil adalah Undang-Undang Nomor 5 Tahun 2014, tentang Aparatur Sipil Negara, yang secara lebih teknis diatur dalam Peraturan Pemerintah Nomor 11, Tahun 2017 tentang Manajamen Aparatur Sipil Negara. Kedua peraturan perundang-undangan tersebut di atas merupakan pedoman pelaksanaan mutasi kepegawaian di setiap instansi pemerintah umum dan daerah.

Untuk mencapai tujuan yang telah ditetapkan, maka mutasi harus berjalan sesuai dengan prosedurnya agar pelaksanaan terhadap rencana mutasi berjalan sesuai dengan yang diharapkan (Sriyana, 2013).

Sastrohadiwiryo (2002), mutasi adalah kegiatan ketenagakerjaan yang berhubungan dengan proses pemindahan fungsi, tanggung jawab, dan status ketenagakerjaan tenaga kerja ke situasi tertentu dengan tujuan agar tenaga kerja yang bersangkutan memperoleh kepuasan kerja yang mendalam dan dapat memberikan prestasi kerja yang semaksimal mungkin kepada organisasi.

Siswanto (2002) bahwa mutasi adalah kegiatan ketenagakerjaan yang berhubungan dengan proses pemindahan fungsi, tanggung jawab dan status ketenagakerjaan ke situasi tertentu dengan tujuan agar tenaga kerja yang bersangkutan memperoleh kepuasan kerja yang dapat meningkatkan produktivitas dan dapat memberi prestasi yang semaksimal mungkin kepada organisasi.

\section{Manfaat Mutasi}

Mutasi pegawai ini merupakan salah satu metode dalam program pengembangan manajemen yang berfungsi untuk meningkatkan efektivitas manajer secara keseluruhan dalam pekerjaan dan jabatannya dengan memperluas pengalaman (Siagian, Ricca Adelina, 2010).

Simamora (2000) manfaat pelaksanaan mutasi adalah (1) memenuhi kebutuhan tenaga kerja di bagian atau unit yang kekurangan tenaga kerja tanpa merekrut dari luar, (2) memenuhi keinginan pegawai sesuai dengan pekerjaan, (3) memberikan jaminan bagi pegawai bahwa dia tidak akan diberhentikan, (4) tidak terjadi kejenuhan, (6) motivasi dan kepuasan kerja yang lebih tinggi, berkat tantangan dan situasi baru yang dihadapi.

Ramlan (2011) menjelaskan Mutasi mengandung segi positif, yaitu (1) Mutasi adalah usaha menempatkan pegawai pada pekerjaan dan jabatan yang sesuai dengan kecakapan dan kemampuannya; (2) Mutasi adalah usaha meningkatkan semangat dan gairah kerja pegawai; (3) Mutasi adalah salah satu usaha menciptakan persaingan yang sehat diantara para pegawai.

\section{Tujuan Mutasi}

Hasibuan (2008) menjelaskan bahwa tujuan mutasi antara lain, adalah: 
a. Untuk meningkatkan produktivitas kerja pegawai. b.Untuk menciptakan keseimbangan antara tenaga kerja dengan komposisi pekerjaan atau jabatan. c. Untuk memperluas atau menambah pengetahuan pegawai. d. Untuk menghilangkan rasa bosan/ jemu terhadap pekerjaannya. e. Untuk memberikan perangsang agar karyawan mau berupaya meningkatkan karier yang lebih tinggi. f. Untuk menyesuaikan pekerjaan dengan kondisi fisik pegawai.g. Untuk mengatasi perselisihan antara sesama pegawai. h. Untuk mengusahakan pelaksanaan prinsip orang tepat pada tempat yang tepat.

Tujuan mutasi yang terkandung dalam Undang -Undang Nomor 5 Tahun 2014, tentang Aparatur Sipil Negara adalah sebagai berikut: a. Peningkatan produktivitas kerja. b. Pendayagunaan pegawai. c. Pengembangan karier. d. Penambahan tenaga-tenaga ahli pada unit-unit yang membutuhkan. e. Pengisian jabatanjabatan lowongan yang belum terisi. $\mathrm{f}$. Sebagai hukuman.

Berkenaan dengan mutasi PNS dimaksud, Nurani (2013) menjelaskan bahwa tujuan mutasi menurut akan berhasil bila dilakukan secara terkoordinasi bukan satu-satu, bersifat menyeluruh dari segenap pelaksanaan tujuan mutasi berikut:

a) Mutasi adalah memindahkan karyawan dari satu pekerjaan lain yang dianggap setingkat atau sejajar.

b) Untuk pelaksanaan harus didasarkan atas pertimbangan matang, sebab bila tidak demikian, mutasi yang dilakukan itu bukannya merupakan tindakan yang menguntungkan, tetapi justru merugikan perusahaan-organisasi kerja.

c) Pada prinsipnya mutasi dilaksanakan agar kita dapat melaksanakan prinsip orang tepat pada tempat yang tepat karena pada saat penempatan pertama hal ini sulit dilaksanakan.

\section{Dasar Pelaksanaan Mutasi}

Hasibuan dalam Nurani (2013) menjelaskan bahwa mengandung 3 (tiga) dasar/landasan pelaksanaan mutasi karyawan, yaitu:

a) Merit system adalah mutasi karyawan didasarkan atas landasan yang bersifat ilmiah, obyektif dan hasil prestasi kerja. Merit system atau carrier system ini merupakan dasar mutasi yang baik, karena (a) Output dan produktivitas kerja meningkat; (b) semangat kerja meningkat; (c) Jumlah kesalahan yang diperbuat menurun; (d) Absensi dan disiplin karyawan semakin baik; dan (e) Jumlah kecelakaan akan menurun.

b) Seniority system adalah mutasi yang didasarkan atas landasan masa kerja, usia dan pengalaman kerja dari karyawan yang bersangkutan. Sistem mutasi ini tidak obyektif, karena kecakapan orang yang dimutasikan berdasarkan senioritas belum tentu mampu memangku jabatan baru.

c) Spoil system adalah mutasi yang didasarkan atas landasan kekeluargaan. Sistem mutasi seperti ini kurang baik karena didasarkan atas pertimbangan suka atau tidak suka (like or dislike).

\section{Promosi Jabatan}

Promosi jabatan adalah peningktan dari seorang tenaga kerja atau pegawai pada suatu bidang tugas yang lebih baik, disbanding dengan sebelumnya dari sisi tanggung jawab yang lebih besar, prestasi, fasilitas, status yang lebih tinggi, tuntutn kecakapan yang lebih tinggi, dan adanya penambahan upah atau gaji serta tunjangan lain Fathoni (2006). Promosi adalah perpindahan yang memperbesar wewenang dan tanggung jawab karyawan ke jabatan yang lebih tinggi di dalam organisasi kewajiban, hak, status dan penghasilannya semakin besar Hasibuan (2002).

\section{Pengertian Promosi}

Manullang dalam Prathita (2013) menjelaskan bahwa promosi berarti kenaikan jabatan, yakni menerima kekuasaan dan tanggung jawab lebih besar dari kekuasaan dan tanggung jawab sebelumnya dalam struktur organisasi sesuatu badan usaha. Flippo yang dikutip oleh Hasibuan (2000) menyatakan bahwa : promosi berarti perpindahan dari suatu jabatan ke 
jabatan yang lain yang mempunyai status yang lebih tinggi. Biasanya perpindahan kejabatan yang lebih tinggi ini disertai dengan peningkatan gaji atau cepat lainnya, walaupun tidak selalu demikian. Sedangkan Andrew F. Sikula yang dikutip oleh Hasibuan (2004) menyatakan bahwa secara teknis promosi adalah suatu perpindahan didalam organisasi dan posisi lainnya yang melibatkan baik peningkatan upah maupun status.

Seseorang dipromosikan karena dianggap mempunyai prestasi rata - rata lebih tinggi dari pegawai yang lain meskipun mungkin oleh pimpinan dinilai prest asi yang ada belum memuaskan (Sudayat, 2009).

\section{Manfaat Promosi}

Manfaat yang dapat diambil dari pelaksanaan promosi jabatan dijelaskan oleh Nitisemito (2003) yaitu ; a. moral dari pegawai yang cenderung lebih dapat ditingkatkan; b. pengetahuan tentang lingkungan kerja yang lebih baik dari pegawai; c. loyalitas yang dapt diharapkan lebih baik dari pegawai yang dipromosikan; d. kebenaran akan datadata dan identittas yang dapt lebih dipercaya.

\section{Tujuan Promosi}

Menurut Manullang (2001:109), perusahaan perlu melakukan promosi untuk mempertinggi semangat kerja karyawan, kemudian dapat menjamin stabilitas kekaryawanan. Beberapa tujuan promosi yang diungkapkan Hasibuan (2007:113) adalah sebagai berikut :

1) Untuk memberikan pengakuan, jabatan, dan imbalan jasa yang semakin besar kepada karyawan yang berprestasi kerja tinggi.

2) Dapat menimbulkan kepuasan dan kebanggaan pribadi, status sosial yang semakin tinggi, dan penghasilan yang semakin besar.

3) Untuk merangsang agar karyawan lebih bergairah kerja, berdisiplin tinggi, dan memperbesar produktivitas kerjanya.

4) Untuk menjamin stabilitas kekaryawanan dengan direalisasinya promosi kepada karyawan dengan dasar dan pada waktu yang tepat serta penilaian yang jujur.

5) Kesempatan promosi dapat menimbulkan keuntungan berantai dalam perusahaan karena timbulnya lowongan berantai.

6) Memberikan kesempatan kepada karyawan untuk mengembangkan kreativitas dan inovasinya yang lebih baik demi keuntungan optimal perusahaan.

7) Untukmenambah/memperluas pengetauan serta pengalaman kerja para karyawan dan ini merupakan daya dorong bagi karyawan lainnya.

8) Untuk mengisi kekosongan jabatan karena pejabatnya berhenti.

9) Karyawan yang dipromosikan kepada jabatan yang tepat, semangat, kesenangan, dan ketenangannya dalam bekerja semakin meningkat sehingga produktifitas meningkat.

10) Untuk mempermudah penarikan pelamar sebab dengan adanya kesempatan promosi merupakan daya pendorong serta perangsang bagi pelamar- pelamar untuk memasukkan lamarannya.

11) Promosi akan memperbaiki status karyawan dari karyawan sementara menjadi karyawan tetap setelah lulus dalam masa percobaannya.

\section{Azas-Azas Promosi}

Menurut Hasibuan (2002: 108) mengemukakan bahwa asas- asas promosi jabatan meliputi : 1. Kepercayaan 2. Keadilan 3. Formasi

\section{Dasar-Dasar Promosi}

Menurut Hasibuan (2002: 109) mengatakan bahwa pedoman yang digunakan sebagai dasar untuk mempromosikan karyawan adalah sebagai berikut: 1. Pengalaman (senioritas) 2. Kecakapan (ability) 3. Kombinasi pengalaman dan kecakapan

$$
\text { Menurut Moekijat (1991) }
$$

Promosi merupakan insentif terbesar dari insentif pegawai. Promosi berarti perbaikan kedudukan dan atau pembayarantambahan. Ramlan (2011) menjelaskan bahwa promosi biasanya didasarkan atas: (1) Kemampuan (sering tidaknya dinilai secara layak); 
Senioritas (biasanya dihitung masa kerja dalam organisasi/lembaga); (3) Ujian (lebih banyak menguji pengetahuan daripada kemampuan); (4) Wawancara perseorangan (menguji kepribadian dan sifat); (5) Rasa senang dan tidak senang perseorangan (dapat berarti penurunan prestasi kerja dan pengurangan efisiensi).

6. Syarat-syarat Promosi

$\begin{array}{lrrr} & \text { Adapun syarat-syarat } & \text { promosi } \\ \text { jabatan } & \text { menurut } & \text { Nitisemito } & \text { dalam } \\ \text { Ningsih } & (2010) & \text { adalah: } & 1 .\end{array}$

Pengalaman. 2. Tingkat pendidikan. 3. Loyalitas. 4. Kejujuran. 5. Tanggung jawab. 6. Kepandaian bergaul. 7. Prestasi kerja. 8. Inisiatif dan kreatif.

\section{Tujuan Penelitian}

Tujuan penelitian merupakan arah dari suatu penelitian yang harus mengacu pada masalah masalah yang telah dirumuskan sebelumnya karena terkait dengan akar masalah yang akan diangkat (Agustinova, 2015). Selain itu, Hadi (2004) menjelaskan bahwa penelitian bertujuan untuk menemukan pengetahuan, mengembangkan pengetahuan dan menguji kebenaran suatu pengetahuan. Oleh karena itu, tujuan penelitian ini adalah untuk mengetahui :

1. Pengaruh motivasi berprestasi terhadap prestasi kerja Pegawai Negeri Sipil Badan Kepegawaian Daerah Kota Blitar

2. Pengaruh mutasi terhadap prestasi kerja Pegawai Negeri Sipil Badan Kepegawaian Daerah Kota Blitar

3. Pengaruh promosi jabatan terhadap prestasi kerja Pegawai Negeri Sipil Badan Kepegawaian Daerah Kota Blitar.

\section{Metode Penelitian}

\section{Jenis Penelitian}

Penelitian ini termasuk penelitian deskriptif yang mana penelitian ini memusatkan perhatian pada masalah-masalah atau fenomena yang bersifat aktual pada saat penelitian dilakukan, kemudian menggambarkan fakta-fakta tentang masalah yang diselidiki sebagaimana adanya diiringi dengan interprestasi yang rasional dan akurat (Nawawi, 2003). Dengan demikian, penelitian yang akan dilakukan adalah penelitian deskriptif kuantitatif.

\section{Populasi dan Sampel}

$$
\text { Sujarweni (2014:65) yang }
$$

menyatakan bahwa Populasi merupakan keseluruhan jumlah yang terdiri atas obyek atau subyek yang mempunyai karakteristik dan kualitas tertentu yang ditetapkan oleh peneliti untuk diteliti dan kemudian ditarik kesimpulan. Populasi adalah wilayah generalisasi yang terdiri atas: obyek/subyek yang mempunyai kualitas dan karakteristik tertentu yang ditetapkan oleh peneliti untuk diteliti dan kemudian ditarik kesimpulannya (Sugiyono, 2014:80). Populasi penelitian ini adalah seluruh Pegawai Negesi Sipil di Lingkungan Badan Kepegawaian Daerah Kota Blitar dengan berbagai karakteristik yang dimilikinya baik jenis kelamin wanita maupun pria, usia, dan pangkat. Jumlah keseluruhan pegawai negeri sipil yang ada di instansi ini sebanyak 35 orang terdiri dari 21 orang berjenis kelamin perempuan dan 14 orang berjenis kelamin laki-laki.

Peneliti merencanakan sampling total/sensus dengan mengambil keseluruhan populasi sebagai sampel penelitian dikarenakan jumlah populasi kurang tidak terlalu banyak atau kurang (Sugiyono, 2014: 67).

\section{Definisi Konsep dan Operasional Identifikasi Variabel}

Variabel yang digunakan dalam penelitian ini dapat diidentifikasi sebagai berikut :

1) Variabel dependen dalam penelitian ini adalah Prestasi Kerja Pegawai Negeri Sipil.

2) Variabel independen adalah motivasi berprestasi, mutasi, dan promosi jabatan.

\section{Definisi Operasional Variabel}

Indikator-indikator variabel diadaptasikan dari penelitian-penelitian sebelumnya, serta beberapa modifikasi atas indikator tersebut, sehingga secara operasional variabel dapat didefinisikan sebagai berikut :

a. Prestasi Kerja Pegawai Negeri Sipil.

Prestasi kerja adalah hasil kerja secara kualitas dan kuantitas yang dicapai oleh seorang karyawan dalam melaksanakan tugasnya sesuai dengan tanggungjawab yang diberikan kepadanya

b. Motivasi Berprestasi.

Motivasi berprestasi adalah dorongan dalam diri seseorang untuk melakukan atau mengerjakan suatu kegiatan atau tugas dengan sebaik-baiknya agar 
mencapai prestasi dengan predikat terpuji.

c. Mutasi.

Mutasi juga disebut transfer adalah bila pegawai tersebut dipindahkan dari satu bidang tugas ke bidang tugas lainnya amaupun tingka setrukturalnya.

d. Promosi Jabatan.

Promosi Jabatan adalah apabila seorang pegawai dipindahkan dari satu pekerjaan ke pekerjaan lain yang lebih tinggi.

\section{Metode Analisis}

Teknik Pengumpulan Data

Sumber Data

Data utama yang digunakan oleh peneliti adalah data primer. Nasution (2009 : 143) menyatakan bahwa data primer adalah data yang diperoleh langsung dari lapangan. Data primer penulis dapatkan melalui kuisioner terkait dengan varibael penelitian. Kuesioner merupakan teknik pengumpulan data yang dilakukan dengan cara memberi seperangkat pertanyaan atau pernyataan tertulis kepada responden untuk dijawabnya" (Sugiyono, 2014 : 142).

Adapun untuk memperoleh gambaran umum terkait dengan object penelitian sumber data yang digunakan adalah sumber data sekunder berupa dokumen, wawancara tidak terstruktur, file dan informasi dari web.

\section{Instrumen Penelitian}

Instrumen merupakan alat ukur yang digunakan peneliti untuk mendapatkan data. Instrumen penelitian adalah suatu alat yang digunakan untuk mengukur fenomena alam maupun sosial yang diamati" (Sugiyono, 2010 : 102). Secara spesifik, semua fenomena tersebut dinamakan variabel penelitian.

Jawaban responden terhadap setiap butir pernyataan pada setiap kuisioner tersebut diberikan skala dengan menggunakan skala linkert. Skala linkert adalah skala yang digunakan untuk mengukur sikap, pendapat, dan persepsi seseorang atau sekelompok orang tentang fenomena sosial yang mempunyai gradasi dari sangat postif sampai sangat negatif (Sugiyono, 2014:93).

\section{Validitas dan Reliabilitas Instrumen}

\section{Validitas}

Untuk mengukur validitas setiap instrumen yang akan digunakan, peneliti menggunakan rumus korelasi dengan mengkorelasikan antara jawaban setiap butir soal tiap instrumen dengan jumlah perolehan skor stiap instrumen dengan bantuan SPSS For Windows Versi 15.

\section{Reliabilitas}

Untuk mengukur reliabilitas setiap instrumen yang akan digunakan, peneliti menggunakan rumus relibilitas (alpa chronbach) dengan jawaban setiap butir soal tiap instrumen dengan bantuan SPSS For Windows Versi 15.

\section{Teknik Analisa Data}

Alat analisis yang akan digunakan meliputi analisi deskriptif dan analisa inferesial menggunakan regresi linear berganda.

\section{Analis Deskriptif}

Analisa Deskriptif adalah metode yang digunakan untuk menggambarkan masing-masing variabel baik variabel bebas maupun variabel terikat (Sugiyono, 2015).

\section{Analisis Inferensial}

Semua analisis menggunakan bantuan Aplikasi SPSS For Windows Versi 15.

1. Uji Normalitas Data

Analisis regresi linier berganda adalah statistik parametrik sehingga data yang akan dinilai harus berdistribusi normal (Sugiyono, 2014:172). Dalam penelitian ini, untuk menguji normalitas data peneliti hendak menggunakan uji kolmogorov-simirnov dan ouput P-Plot. Data dikatkan normal bila :

a) Nilai Probabilitas Uji kolmogorovsimirnov lebih dari 0.05

b) Sebaran data terletak disekitar garis lurus pada ouput P-Plot.

2. Uji Linieritas Data

Uji linieritas data terpenuhi bila Siginigfikansi Deviation From Linierity lebih besar dari 0,05 (Sudarmanto, 2005).

3. Uji Multikolinearitas

Supranto (2009:280) menjelaskan bahwa bila asumsi ini terjadi maka pengaruh masing-masing variabel bebas terhadap variabel terikat tidak bisa dibedakan.

Jika hasil uji asumsi menunjukkan normalitas data, tidak adanya autokorelasi, multikolineritas maka alat analisis regresi linier berganda bisa digunakan. Analisis dilakukan baik secara parsial maupun bersama-sama untuk menguji hipothesis 1,2 dan 3. 
Adapun rumus regresi linier berganda yang digunakan adalah :

$$
\begin{aligned}
& \mathrm{Y}=\mathrm{a}+\mathrm{bX} 1+\mathrm{bX} 2+\mathrm{bX} 3+\mathrm{e} \\
& \text { Dimana : } \\
& \mathrm{Y}=\text { Prestasi Kerja PNS } \\
& \text { a } \quad=\text { Konstanta } \\
& \mathrm{b}=\text { Koefesien regresi } \\
& \mathrm{X} 1=\text { Motivasi Berprestasi } \\
& \mathrm{X} 2=\text { Mutasi } \\
& \text { X3 }=\text { Promosi Jabatan }
\end{aligned}
$$

Sedangkan untuk menguji hipothesis dan menjawab rumusan masalah yang keempat, kelima dan keenam maka peneliti hendak menggunakan koefesien determinasi baik secara parsial mupun bersama-sama yang diperoleh dari pengolahan SPSS For Windows Versi 15.

\section{Hasil Penelitian dan Implikasi Deskripsi Masing-masing Variabel}

Bahwa kondisi umum prestasi kerja pegawai negeri sipil pada Badan Kepegawaian Daerah Kota Blitar memiliki prestasi yang tinggi dengan skor rata-rata sebesar 3.94. Sedangkan secara umum motivasi berprestasi pegawai pada level tinggi skor rata rata sebesar 4,17. Adapun kondisi umum proses mutasi terhadap prestasi kerja pegawai negeri sipil memiliki skor yang tinggi / baik dengan skor rata-rata sebesar 3,01. Selanjutnya kondisi umum promosi jabatan terhadap prestasi kerja memiliki prestasi yang tinggi dengan skor rata-rata sebesar 4,09.

\section{Analisis Data}

Uji Kualitas Data, semua data yang ditulis dalam penelitian ini pengujian dengan realibiltas dan validitas dan semua memenuhi syarat yang valid dan reliable.

Selanjutnya dengan pengujian Uji

\begin{tabular}{|c|c|c|c|c|c|}
\hline \multicolumn{6}{|c|}{ ModelSummary ${ }^{b}$} \\
\hline Model & $R$ & RSquare & $\begin{array}{l}\text { Adjusted } \\
\text { RSquare } \\
\end{array}$ & $\begin{array}{l}\text { Std. Error of } \\
\text { the Estimate }\end{array}$ & $\begin{array}{l}\text { Durbin- } \\
\text { Watson }\end{array}$ \\
\hline 1 & $670^{a}$ & ,449 &, 396 & 1,68977 & 1,944 \\
\hline
\end{tabular}
Normalitas, Uji Linieritas, Uji Multikolinineritas, Uji Autokolerasi dan Uji Herteroskadestisitas semua memenuhi syarat sesuai kaidah yang ditentukan. Adapun analisa Uji regresi, uji model hubungan dengan hasil dalam tabel sebagai berikut : Tabel Nilai R

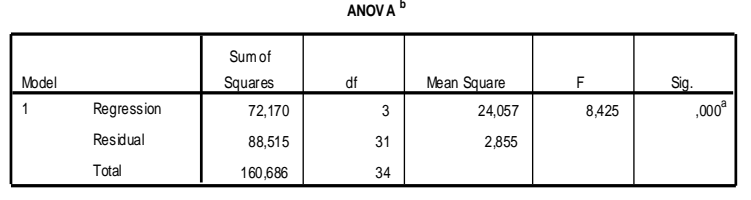

a. Predictors: (Constant), Promosi Jabatan, Mutasi, Motivasi Berprestasi

b. Dependent Variable: Prestasi Keria

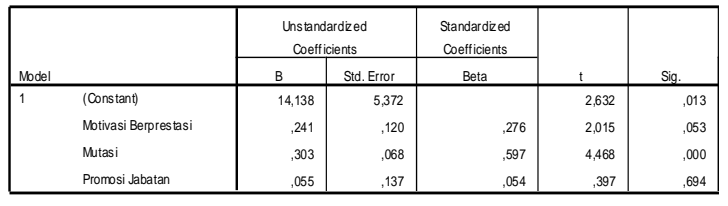

Implikasi

Pengaruh motivasi berprestasi terhadap prestasi kerja

Hasil penelitian menunjukkan koefesien sebesar 0,241 denga thitung 2,015 dan nilai signifikansi sebesar 0,053 yang mana nilai signifikansi ini jauh lebih kecil dari taraf signifikansi yang digunakan oleh peneliti yaitu taraf signifikansi 0,1 atau dengan toleransi kesalahan sebesar $10 \%$.

Dengan hasil pengujian tersebut maka hipotesis yang menyatakan pengaruh motivasi berprestasi terhadap prestasi kerja pegawai dapat diterima.

Nilai-nilai pengujian tersebut menunjukkan adanya signifikansi pengaruh motivasi berprestasi terhadap prestasi kerja pegawai negeri sipil pada Badan Kepegawaian Daerah Kota Blitar. Hasil ini juga mengkonfirmasi kondisi prestasi kerja yang berada pada level tinggi / baik akibat dari motivasi berprestasi pegawai negeri sipil yang bertugas pada organisasi perangkat daerah ini yang tinggi/baik pula.

Hasil deskripsi terhadap variabel motivasi berprestasi menunjukkan bahwa sebagian besar pegawai negeri sipil pada organisasi perangkat daerah ini menyatakan bahwa mereka merasa bahwa bersalah bila tidak berhasil melaksanakan pekerjaan seperti yang seharusnya. Selain itu, mereka juga mengatakan bahwa resiko adalah hal yang pasti dalam setiap keputusan yang diambil. Selaras dengan hal ini, Priansa (2016:208) menjelaskan bahwa orang yang memiliki $n$-ach tinggi biasanya selalu ingin menghadapi tantangan baru dan mencari tingkat kebebasan yang tinggi. Kondisi ini dijelaskan oleh Mc. Celland dalam Sunyoto (2015:197) bahwa pada dasarnya seseorang bekerja 
memiliki energi potensial yang dapat dimanfaatkan.

\section{Pengaruh mutasi terhadap prestasi kerja}

Berdasarkan hasil penelitian, pengaruh mutasi terhadap prestasi kerja pegawai negeri sipil ditunjukkan dengan nilainilai yang didapatkan. Jika mengacu pada tabel 4.11, maka akan didapatkan nilai-nilai analisis regersi linier berganda yaitu nilai koefesien variabel mutasi sebesar 0,303 dengan $\mathrm{t}$ hitung sebesar 4,468 dan nilai signifikansi sebesar 0,000 jauh lebih kecil dari taraf sifnifikansi yang diterapkan oleh peneliti yaitu 0,1 .

Dengan hasil pengujian tersebut maka hipotesis yang menyatakan pengaruh mutasi terhadap prestasi kerja pegawai dapat diterima.

Nilai-nilai pengujian tersebut menunjukkan bahwa, mutasi signifikan berpengaruh signifikan terhadap prestasi kerja pegawai negeri sipil Badan Kepegawaian Daerah Kota Blitar. Sebagaimana diketahui sebelumnya bahwa pada umumnya responden menyatakan bahwa mutasi pada lembaga ini sudah mengacu pada prinsip-prinsip merit system meskipun masih terdapat hal-hal yang berbau seniority system. Hasibuan dalam Nurani (2013) menjelaskan bahwa merit system adalah mutasi karyawan didasarkan atas landasan yang bersifat ilmiah, obyektif dan hasil prestasi kerja sedangkan seniority system adalah mutasi yang didasarkan atas landasan masa kerja, usia dan pengalaman kerja dari karyawan yang bersangkutan.

Pengaruh promosi jabatan terhadap prestasi kerja

Hasil perhitungan output SPSS sebagaimana tertera pada tabel 4.11 menyatakan bahwa variabel promosi jabatan memiliki koefesien 0,055 dengan $t$ hitung sebesar 0,397 dan nilai signifikansi 0,694. Nilai signifikansi 0,694 berada jauh lebih besar dari taraf signifikansi yang telah ditetapkan yaitu 0,1 atau tolerasi kesalahan sebesar $10 \%$.

Dengan hasil pengujian tersebut maka hipotesis yang menyatakan pengaruh promosi jabatan terhadap prestasi kerja pegawai tidak dapat diterima atau ditolak pada pegawai negeri sipil Badan Kepegawaian Daerah Kota Blitar.
Nilai-nilai pengujian ini menunjukkan bahwa variabel promosi jabatan tidak signifikan atau tidak berpengaruh terhadap prestasi kerja pegawai negeri sipil yang ada pada organisasi perangkat daerah ini.

Berdasarkan deskripsi variabel promosi jabatan yang telah dikemukakan di depan menjelaskan fenomena ini. Dalam desripsi tentang variabel promosi jabatan pegawai negeri sipil, menurut sebagian besar responden sudah sangat baik. Promosi jabatan yang ada pada OPD ini dilaksanakan dengan mempertimbangkan loyalitas, inisiatif dan pengalaman kerja pegawai negeri sipil. Sebagian besar, mereka menyatakan setuju dan sangat setuju bila promosi jabatan yang ada di opd ini selalu melaksanakan perintah dari atasan, melakasanakan pekerjaan dengan penuh cinta, dan selalu berinovasi dalam melaksanakan tugas. Dengan demikian, mereka tidak memikirkan promosi ataupun kedudukan mereka. Bagi mereka yang penting adalah bekerja karena bekerja adalah ibadah.

\section{Simpulan}

Dengan memperhatikan hasil penelitian, peneliti mengambil beberapa kesimpulan sebagai berikut :

1. Adanya signifikansi pengaruh motivasi berprestasi terhadap prestasi kerja pegawai negeri sipil pada Badan Kepegawaian Daerah Kota Blitar.

2. Mutasi signifikan berpengaruh signifikan terhadap prestasi kerja pegawai negeri sipil pada Badan Kepegawaian Daerah Kota Blitar.

3. Bahwa variabel promosi jabatan tidak signifikan atau tidak berpengaruh terhadap prestasi kerja pegawai negeri sipil yang ada pada Badan Kepegawaian Daerah Kota Blitar.

4. Secara bersama-sama variabel motivasi berprestasi, mutasi dan promosi jabatan berpengaruh terhadap prestasi kerja pegawai negeri sipil di Badan Kepegawaian Daerah Kota Blitar.

\section{Daftar Pustaka}

Anwar Prabu Mangkunegara. 2009. Evaluasi Kinerja Sumber Daya Manusia. Bandung: Penerbit Refika Aditama. 
Priansa, D. J. (2016). Perencanaan \& Pengembangan SDM. Bandung: Alfabeta.

Hasibuan, M. (2008). Manajemen Sumber Daya Manusia. Edisi Revisi.Jakarta: PT Bumi Aksara

Sunyoto, S.H., S.E., M.M. (2015). Perilaku Konsumen dan. Pemasaran. Yogyakarta: CAPS

PERKA BKN NOMOR 21 TAHUN 2011 PEDOMAN PELAKSANAAN EVALUASI JABATAN PNS

Undang-Undang Republik Indonesia No. 5 Tahun 2014 tentang Aparatur Sipil Negara

Undang-undang Nomor 5 Tahun 2014 tentang Aparatur Sipil Negara

Handoko, T. Hani. 2001. Manajemen Personalia dan Sumber Daya Manusia. Yogyakarta: BPFE Yogyakarta

Robbins, Stephen P \& Judge, Timothy A. 2013. Organizational Behavior Edition. 15. New Jersey: Pearson Education

Siagian, Sondang P. (2004). Manajemen Sumber Daya Manusia. Jakarta: Bumi Aksara 